\title{
PENDEKATAN ANALISIS KEPUTUSAN PADA EFEKTIVITAS BIAYA TERAPI SEFTRIAKSON-SIPROFLOKSASIN PASIEN INFEKSI SALURAN KEMIH DI RSUD JOMBANG
}

\section{DECISION TREE ANALYSIS APPROACH IN COST-EFFECTIVENESS CEFTRIAXONE-CIPROFLOXACIN TREATMENT OF URINARY TRACT INFECTIONS IN RSUD JOMBANG}

\author{
Anggi Restyana ${ }^{1 *}$, Rina Herowati ${ }^{1}$, Tri Murti Andayani ${ }^{2}$ \\ ${ }^{1}$ Universitas Kadiri, Kediri \\ ¿Universitas Setia Budi, Surakarta \\ ${ }^{3}$ Universitas Gadjah Mada, Yogyakarta \\ Penulis Korespondensi: \\ Anggi Restyana \\ Universitas Kadiri \\ anggieresty08@gmail.com
}

\begin{abstract}
ABSTRAK
Di rumah sakit, seftriakson atau siprofloksasin diresepkan untuk memberikan cakupan empiris terhadap patogen E.coli di antara pasien ISK. Adanya penggunaan antibiotik yang berbeda pada masing-masing pasien mengakibatkan besarnya biaya obat yang diperlukan pasien bervariasi. Hal ini belum menjamin bahwa obat memiliki efektivitas yang lebih tinggi. Dilakukan penelitian ini bertujuan untuk menentukan terapi yang lebih cost-effective antara penggunaan seftriakson dan siprofloksasin pada pasien infeksi saluran kemih dengan metode pohon keputusan. Diharapkan hasil penelitian ini dapat memberikan pertimbangan dalam pemilihan terapi ISK dalam Pedoman Pelayanan Klinik.

Penelitian dilakukan dengan membandingkan total biaya medis langsung dari perspektif rumah sakit dan efektivitas yang dilihat berdasarkan probabilitas sembuh tanpa efek samping dari terapi seftriakson dan siprofloksasin, melakukan analisa keputusan dengan metode Decision Tree, menentukan seftriakson yang lebih costeffective pada pasien ISK di RSUD Kabupaten Jombang 2017, serta dilkukan analisa sensitivitas. Desain penelitian adalah studi cross-sectional retrospektif terhadap data rekam medis dan administrasi keuangan tahun 2017. Pengambilan sampel dilakukan secara purposive sampling.

Jumlah pasien yang dilibatkan dalam analisis 64 pasien, yaitu 32 pasien menggunakan seftriakson dan 32 pasien menggunakan siprofloksasin. Hasil penelitian menunjukkan, antibiotik yang lebih cost-effective dalam pengobatan ISK adalah seftriakson dengan probabilitas 0,84, nilai $A C E R$ sebesar Rp. $1.366 .938,13$ dan nilai ICER diperoleh Rp. -835.288,32 untuk setiap peningkatan efektivitas.
\end{abstract}

Kata kunci : decision tree, efektivitas biaya terapi, Infeksi Saluran Kemih, seftriakson, siprofloksasin 


\begin{abstract}
In hospitals, ceftriaxone or ciprofloxacin are prescribed to provide empirical coverage of E. coli pathogens among UTI patients. The use of different antibiotics in each patient resulted in the amount of drug costs that the patient needed varied. It has not been guaranteed that the drug has higher effectiveness. This research aims to determine a more cost-effective treatment between the use of ceftriaxone or ciprofloxacin in urinary tract infection patients with a method of decision tree. Expected results of this research can give consideration in the selection of UTI therapy in the clinical services guidelines.

This study was conducted by comparing total direct medical costs and effectiveness based on the probability of patient that has recovery without side-effect from treatment of ceftriaxone and ciprofloxacin injections, making decision analysis with decision tree method, and determining the more cost-effective is ceftriaxone in UTI patients in RSUD Kab. Jombang 2017 and conducted sensitivity analysis. Study design was a retrospective cross-sectional on medical records and financial administration data for 2017. Sampling was carried out by purposive sampling.

The subject were 64 patient who meet the inclusion criteria. In which, there were 32 patients on each group therapy of ceftriaxone and ciprofloxacin. The results showed that ceftriaxone was more cost-effective with effectiveness value 0,84, ACER value Rp $1.366 .938,13$ and ICER value Rp $-835.288,32$ for each increase in effectiveness.
\end{abstract}

Keywords: decision tree, cost effectiveness, urinary tract infection, ceftriaxone, ciprofloxacin 


\section{PENDAHULUAN}

Infeksi saluran kemih (ISK) didefinisikan sebagai keberadaan mikroorganisme di dalam urin yang memiliki potensi untuk menyerang jaringan saluran kemih dan struktur lain yang berdekatan (Dipiro et al., 2012). ISK merupakan salah satu penyakit infeksi yang paling mendominasi. Di Indonesia, pada umumnya penyebab utama dari ISK adalah bakteri Escherichia coli dimana sebesar $50-90 \%$ pasien yang mengalami rawat inap di rumah sakit terdiagnosa ISK dengan bakteri tersebut (Pranoto et al, 2012). Di rumah sakit, fluorokuinolon atau sefalosporin biasanya diresepkan untuk memberikan cakupan empiris terhadap patogen E.coli di antara pasien ISK (Bidel et al, 2016). Sebagian besar antibiotik yang digunakan di rumah sakit adalah antibiotik spektrum luas, yaitu golongan sefalosporin dan florokuinolon. Golongan florokuinolon yang sering dipakai adalah siprofloksasin. Selain harganya yang lebih murah, siprofloksasin juga unggul dalam cara pemakaian yaitu oral dan diminum dua kali atau sekali dalam sehari.

Efektivitas siprofloksasin ditunjukkan pada penelitian sistematik review tahun 2015 yang menyatakan bahwa siprofloksasin memiliki efektivitas terapi pada ISK non komplikasi maupun ISK komplikasi. Hal ini juga berlaku pada seftriakson yang juga memiliki efektivitas pada terapi ISK komplikasi. Pada penelitian yang dilakukan oleh HsinAn Lin et a/ tahun 2016 menyatakan bahwa seftriakson selain memiliki efektivitas pada terapi ISK Komplikasi, obat ini juga memiliki costyang lebih rendah dibandingkan dengan ertapenem dan levofloxacin.

Efektivitas seftriakson dibuktikan bahwa di rumah sakit, seftriakson digunakan sebagai salah satu pilihan dalam terapi ISK. Antibiotik seftriakson juga merupakan antibiotik pilihan sebagai alternatif selain golongan florokuinolon (Abbo, 2014). Pada kasus pielonefritis akut, sefalosporin seftriakson merupakan antibiotik pilihan yang digunakan jika terdapat resistensi pada golongan florokuinolon (Lane et al., 2012). Penelitian menunjukkan pola sensitivitas terhadap bakteri E.coli menunjukkan sensitivitas E.coli ESBL positif sebesar $0 \%$ pada antibiotik seftriakson dan $13,7 \%$ positif pada siprofloksasin.

Salah satu alat yang dapat digunakan untuk analisa efektivitas biaya adalah analisa keputusan metode Pohon Keputusan. Peranan pohon keputusan ini adalah sebagai Decision Support Tool untuk membantu manusia dalam mengambil suatu keputusan (Andayani, 2013).

Berdasarkan hal tersebut peneliti ingin meneliti analisa efektivitas biaya antara siprofloksasin dan seftriakson untuk membuktikan apakah seftriakson lebih costeffective dibandingkan siprofloksasin pada terapi pasien infeksi saluran kemih di RSUD Jombang tahun 2017. 


\section{TUJUAN}

Untuk mengetahui apakah seftriakson lebih cost-effective dibandingkan siprofloksasin pada terapi pasien infeksi saluran kemih di RSUD Jombang tahun 2017 dengan metode pohon keputusan.

\section{METODE PENELITIAN}

Rancangan penelitian yang digunakan adalah menurut perspektif rumah sakit dengan metode observasional analitik studi cross-sectional retrospektif terhadap data sekunder berupa catatan rekam medis dan data keuangan. Penelitian dilakukan di Rumah Sakit Umum Daerah Kab. Jombang bagian rekam medis rawat inap, keuangan dan instalasi farmasi rumah sakit dari bulan Juni sampai Juli 2018.

Populasi adalah pasien ISK yang yang dirawat inap pada tahun 2017. Sampel penelitian adalah data semua pasien ISK yang memenuhi kriteria inklusi di Rumah Sakit Umum Daerah Kab. Jombang pada tahun 2017. Pengambilan sampel dilakukan secara purposive sampling. Jumlah sampel yang diambil adalah 32 sampel per kelompok terapi. Jumlah ini berdasarkan sampel total yang memenuhi kriteria inklusi selama pengambilan data.

Kriteria inklusi dalam penelitian ini diantaranya Pasien berumur $\geq 26$ tahun yang dirawat di kelas 3 RSUD Kab. Jombang minimal dalam 1 hari, yang menggunakan terapi seftriakson dan siprofloksasin sebagai terapi infeksi saluran kemih pada periode perawatan Januari hingga Desember 2017.

Bahan dalam penelitian ini adalah sebagai berikut, data rekam medis pasien, rincian biaya terapi ISK dan rincian penggunaan obat seftriakson atau siprofloksasin oleh pasien selama pasien dirawat di RSUD Kab. Jombang.

Alat yang digunakan adalah Formulir pengambilan data yang dirancang sesuai dengan kebutuhan penelitian meliputi : data demografi pasien, data obat seftriakson dan siprofloksasin, data biaya terapi ISK yang dikeluarkan pasien selama perawatan dengan terapi seftriakson atau siprofloksasin pada infeksi saluran kemih periode Januari hingga Desember 2017, data biaya terapi obat dan alkes per pasien berdasarkan harga normatif yang mengacu pada harga obat dan alkes di RSUD Kab. Jombang pada tahun 2017.

Jalannya penelitian adalah sebagai berikut.

Tahap 1: Pengambilan data dari rekam medis terhadap pasien dari 1 Januari 2017 sampai 31 Desember 2017, kemudian dilakukan pencatatan pada lembar pengamatan. Tahap 2 : Pengambilan data keuangan yakni biaya terapi ISK (biaya instalasi rawat darurat, kelas perawatan, pemeriksaan penunjang dan instalasi gizi dan biaya penunjang terapi) dan biaya obat yang diperlukan oleh pasien selama dirawat.

Tahap 3 : Analisis Data yang dilakukan adalah Analisa karakteristik dilakukan pada 4 karakteristik pasien yakni jenis kelamin, usia, lama rawat, antibiotik oral dengan metode chi square. Pengukuran efektivitas terapi dilakukan dengan menghitung probabilitas 


\section{JURNAL INOVASI}

FARMASI INDONESIA

(JAFI)

sembuh, kegagalan terapi dan efek samping, kemudian menganalisa biaya total dengan kategorisasi sembuh, gagal terapi dan munculnya efek samping.

Tahap 4 : Analisa efektivitas biaya dilakukan dengan menggunakan dengan analisa keputusan, Pemodelan Decision Tree untuk membandingkan antara dua antibiotik yang digunakan dalam terapi ISK, menghitung Expected Monetary Value (EMV) seftriakson dan siprofloksasin, menghitung nilai ACER dan ICER, kemudian dilakukan analisa perbandingan dengan menggunakan diagram efektivitas biaya dan analisa sensitivitas.

Analisa sensitivitas dilakukan untuk mengetahui sejauh mana perubahan nilai biaya atau efektivitas yang digunakan untuk menghitung ACER dapat mempengarui kesimpulan. Pada analisis ini, dilakukan pengulangan data analisis setelah mengubah nilai beberapa variabel untuk melihat dampak jika variabel tersebut diubah terhadap hasil secara keseluruhan.

\section{HASIL DAN PEMBAHASAN}

Gambaran subyek penelitian

Terdapat 161 pasien ISK yang mendapatkan terapi antibiotik di RSUD Kab. Jombang pada tahun 2017. Sebanyak 64 pasien ISK yang mendapatkan terapi antibiotik seftriakson dan siprofloksasin. Sebanyak 32 pasien yang mendapatkan terapi seftriakson dan memenuhi kriteria inklusi dan banyak 32 pasien yang mendapatkan terapi siprofloksasin dan memenuhi kriteria inklusi.

Pada penelitian ini ditemukan bahwa perbandingan laki-laki dan perempuan menggunakan terapi seftriakson adalah 13 pasien (40,6\%) : 19 pasien (59,4\%) sedangkan pada terapi siprofloksasin perbandingan laki-laki dan perempuan adalah 12 pasien $(37,5 \%)$ : 20 pasien (62,5\%). Kemudian dilakukan uji statistik dengan metode chi square diperoleh nilai $p=0,798(p>0,05)$. Dari nilai $p$ tersebut dapat diketahui bahwa proporsi jenis kelamin tidak terdapat perbedaan bermakna.

Hasil menunjukkan bahwa kelompok usia antara 56-65 tahun adalah kelompok yang paling banyak menerima seftriakson (34,4\%). Sedangkan kelompok usia antara 46-55 tahun adalah kelompok yang paling banyak menerima siprofloksasin $(53,1 \%)$. Namun, setelah dilakukan uji statistik diperoleh nilai $p=0,051$. Secara statistik dapat disimpulkan bahwa tidak terdapat perbedaan bermakna pada kelompok usia pengguna terapi seftriakson dan kelompok terapi siprofloksasin. Hal yang sama diperoleh pada penelitian yang dilakukan oleh Ruru et al (2018) yang mana ditemukan bahwa pasien pada kelompok usia 56 hingga 65 tahun lebih rentan terjadi atau beresiko mengalami infeksi saluran kemih. Hal ini disebabkan karena pada usia tersebut telah terjadi penurunan daya tahan tubuh sehingga dapat terjadi peningkatan kerentanan terhadap infeksi (Kasmed et al, 2007). 
JURNAL INOVASI

FARMASI INDONESIA

(JAFI)

Tabel I Gambaran karakteristik pasien antara kelompok terapi seftriakson dan siprofloksasin

\begin{tabular}{cclll}
\hline & Karakteristik & \multicolumn{2}{c}{ Kelompok terapi } & P \\
\cline { 3 - 4 } & & \multicolumn{1}{c}{ Seftriakson } & Siprofloksasin & \\
\hline Jenis & Laki-laki & $13(40,6 \%)$ & $12(37,5 \%)$ & 0,798 \\
Kelamin & Perempuan & $19(59,4 \%)$ & $20(62,5 \%)$ & \\
Usia & $26-35$ & $5(15,6 \%)$ & $3(9,4 \%)$ & 0,051 \\
& $36-45$ & $5(15,6 \%)$ & $4(12,5 \%)$ & \\
& $46-55$ & $7(21,9 \%)$ & $17(53,1 \%)$ & \\
& $56-65$ & $11(34,4 \%)$ & $3(9,4 \%)$ & \\
Lama & $>65$ tahun & $4(12,5 \%)$ & $5(15,6 \%)$ & \\
Rawat & $1-3$ hari & $9(28,1 \%)$ & $2(6,3 \%)$ & 0,114 \\
& $4-5$ hari & $16(50 \%)$ & $24(75 \%)$ & \\
Antibiotika & $>5$ hari & $7(21,9 \%)$ & $6(18,8 \%)$ & \\
oral & Siprofloksasin & $1(3,1 \%)$ & $4(12,5 \%)$ & 0,162
\end{tabular}

Sumber: data mentah yang diolah

Hasil penelitian menunjukkan bahwa pasien dengan lama rawat 4-5 hari merupakan jumlah terbanyak dengan perbandingan antara terapi seftriakson dan siprofloksasin adalah 16 pasien (50\%) : 24 pasien (75\%) dan hasil nilai $p=0,114$. Dengan nilai $p>0,05$ dapat disimpulkan bahwa tidak terdapat perbedaan bermakna antara lama rawat dengan kelompok terapi seftriakson dan siprofloksasin.

Hasil penelitian menunjukkan bahwa antibiotik oral siprofloksasin yang diberikan kepada pasien dengan kelompok terapi seftriakson dan siprofloksasin sebanyak 1 pasien $(3,1 \%)$ : 4 pasien (12,5\%). Hasil uji statistik diperoleh nilai $p=0,162$. Hal ini menunjukkan nilai $p>0,05$ sehingga tidak terdapat perbedaan yang bermakna antara pemberian antibiotik oral dengan kelompok terapi seftriakson dan siprofloksasin.

\section{Analisa Efektivitas}

Efektivitas penggunaan seftriakson dibandingkan dengan siprofloksasin diukur dari probabilitas terjadinya sembuh dan efek samping. Besarnya probabilitas dapat dilihat pada tabel II.

Sembuh, dengan ciri-ciri suhu normal, leukosit menurun hingga mencapai rentang lakilaki $=3,8-10,6 \times 1^{03} / \mathrm{ul}$, perempuan $=3,6-11 \times 1^{03} / \mathrm{ul}$ dan sedimen leukosit (-) dengan durasi pemberian injeksi dan length of Stay (LOS) maksimal 5 hari. Sedangkan efek samping dinilai berdasarkan kejadian tidak diharapkan yang muncul secara klinis selama perawatan akibat penggunaan antibiotik seftriakson atau siprofloksasin dan tercatat di rekam medis. 
JURNAL INOVASI

FARMASI INDONESIA

(JAFI)

Tabel II. Probabilitas pada masing-masing kelompok terapi

\begin{tabular}{ccc}
\hline Outcome & \multicolumn{2}{c}{ Kelompok Terapi } \\
\cline { 2 - 3 } & Seftriakson & Siprofloksasin \\
& $(\%)$ & $(\%)$ \\
\hline Sembuh & 87,5 & 81,25 \\
Efek Samping & 28.5 & 32 \\
\hline
\end{tabular}

Dari tabel II tersebut terlihat bahwa penggunaan kelompok terapi seftriakson memiliki persentase kesembuhan yang lebih tinggi dibandingkan penggunaan kelompok terapi siprofloksasin. Selain itu persentase terjadinya efek samping pada kelompok terapi seftriakson lebih kecil daripada kelompok terapi siprofloksasin. Oleh karena pasien kelompok terapi seftriakson lebih banyak probabilitas kesembuhan dan lebih sedikit probabilitas efek sampingnya daripada kelompok terapi siprofloksasin, maka dapat disimpulkan bahwa seftriakson lebih efektif dibandingkan siprofloksasin.

Penelitian Oreagba et al (2017) menunjukkan terjadinya reaksi yang tidak diinginkan pada terapi golongan florokuinolon di populasi penduduk Nigeria. Sebanyak 256 kasus ADR akibat florokuinolon dari 18.527 laporan ADR (Adverse Drug Reaction). Persentase ADR antibiotik siprofloksasin sebesar 43,8\%. Adapun ADR yang muncul diantaranya gangguan syaraf $(22,4 \%)$, gangguan pencernaan $(21,9 \%)$, gangguan kulit $(21,5 \%)$, pruritus (7,6\%), nyeri abdomen (6,3\%), muntah (6,3\%) dan kulit kemerahan (5\%).

Penelitian senada pada kelompok terapi seftriakson yang dilakukan pada antibiotik sefalosporin oleh Crotty et al(2017). Penelitian dilakukan secara retrospektif dari rekam medik elektronik dimana pasien alergi penisilin dan menerima setidaknya 1 kali dosis seftriakson. Hasil penelitian menunjukkan tidak ada reaksi alergi yang ditemukan ( 0 dari 69 sampel).

\section{Analisis Biaya}

Pada penelitian ini dilakukan analisis biaya dengan sudut pandang rumah sakit meliputi:

1. Biaya sembuh

Biaya sembuh terdiri dari biaya terapi ISK dan biaya antibiotik seftriakson atau siprofloksasin. Pada tabel 3 menunjukkan bahwa setiap pasien memerlukan biaya yang tidak sama. Hal ini disebabkan lama rawat pada masing-masing pasien berbeda. Semakin lama pasien dirawat maka semakin besar pula biaya yang harus diperlukan pasien.

Berdasarkan tabel 3 juga dapat diketahui bahwa biaya yang mendominasi adalah biaya terapi ISK sebesar $92 \%$ total biaya. Hal ini disebabkan biaya terapi ISK terdiri dari biaya instalasi rawat darurat, biaya kelas perawatan, biaya pemeriksaan penunjang, biaya instalasi gizi dan biaya penunjang terapi. Pada tabel 4 menggambarkan total biaya terapi ISK dan biaya antibiotik siprofloksasin. Perbandingan dilakukan dengan memperhatikan antara biaya kelompok terapi seftriakson dan siprofloksasin. Pasien ISK sembuh pada kelompok terapi seftriakson 
mengeluarkan biaya yang lebih besar daripada biaya yang diperlukan pasien pada kelompok terapi siprofloksasin. Hal ini disebabkan harga antibiotik seftriakson lebih mahal daripada harga antibiotik siprofloksasin. Dimana harga antibiotik seftriakson Rp $12.324,88$ sedangkan harga antibiotik siprofloksasin Rp 11.496,76. Namun hal ini tidak semata-mata menjadi suatu kesimpulan dengan harga antibiotik yang lebih mahal maka lebih efektif. Keefektifan suatu terapi antibiotik juga dipengaruhi angka kejadian (probabilitas) sembuh dan efek samping.

2. Biaya gagal terapi

Biaya terapi ISK hanya terdiri dari biaya kelas perawatan dan biaya penunjang terapi. Pada tabel 5 diperoleh biaya yang diperlukan pasien ISK yang mengalami kegagalan terapi pada kelompok terapi seftriakson dan pada kelompok terapi siprofloksasin.

Berdasarkan kelompok biaya gagal terapi, pada tabel 5 diketahui perbandingan biaya kelas perawatan antara kelompok terapi seftriakson dan siprofloksasin. Biaya kelas perawatan dipengaruhi oleh tingkat keparahan, maka lama rawat menjadi semakin lama. Semakin panjang lama rawat maka biaya kelas perawatan semakin besar.

Pada tabel 5 juga menunjukkan rata-rata biaya penunjang terapi. Penunjang terapi yang diberikan kepada pasien beragam tergantung dari kondisi pasien. Besarnya penunjang terapi dipengaruhi oleh jenis dan jumlah alat kesehatan maupun obat yang digunakan.

Pada tabel 5 diketahui biaya antibiotik saat pasien mengalami kegagalan terapi. Dimana biaya antibiotik dalam hal ini dihitung pada hari keenam atau lebih perawatan. Pasien dengan kelompok terapi seftriakson membutuhkan lama rawat yang lebih pendek daripada kelompok terapi siprofloksasin.

3. Biaya efek samping

Pada tabel 6 diketahui bahwa biaya efek samping dipengaruhi oleh tingkat keparahan efek samping dan lama sembuhnya efek samping. Maknanya, efek samping yang terjadi pada pasien dengan kelompok terapi siprofloksasin memiliki tingkat keparahan lebih tinggi sehingga membutuhkan waktu terapi yang lebih lama untuk menghilangkan efek samping tersebut.

\section{Analisa Efektivitas Biaya}

Analisa efektivitas biaya dilakukan dengan menghitung nilai EMV atau perkiraan moneter. EMV adalah perhitungan perkalian yang melibatkan probabilitas kejadian dalam suatu pemilihan alternatif terapi dan biaya yang diperlukan pasien dengan outcome tertentu.

Probabilitas dalam penelitian ini adalah persentase kesembuhan dan tidak munculnya efek samping. Efektivitas mempengaruhi biaya terapi sehingga terlibat dalam pengambilan keputusan alternatif mana yang memberikan efektivitas-biaya terbaik.

Kemudian dilakukan analisa keputusan dengan metode Decision Tree. Analisa keputusan membantu dalam menentukan pilihan keputusan yang paling baik. Decision tree dibangun dengan membandingkan dua kategori terapi antibiotik yaitu seftriakson dan 
siprofloksasin (Gambar 1). Kemudian berdasarkan nilai EMV (biaya dihitung dengan membandingkan biaya medik langsung dan efektivitas dari kelompok terapi seftriakson dan kelompok terapi siprofloksasin) dilakukan perhitungan Average Cost-Effectiveness Ratio/ ACER dan Incremental Cost-Effectiveness Ratio/ICER.

Hasil perhitungan ACER dan ICER dapat dilihat pada tabel 7. Pada tabel 7 dapat disimpilkan bahwa seftriakson lebih cost-effective dibandingkan siprofloksasin pada pasien ISK. Hal ini bisa dilihat dari nilai ACER yang lebih rendah daripada siprofloksasin. Berdasarkan gambar 2 ditunjukkan antibiotik seftriakson menempati kuadran Adopt. Maknanya, antibiotik seftriakson memiliki efektivitas lebih tinggi dengan biaya yang lebih rendah dibandingkan siprofloksasin. Sehingga, seftriakson dapat digunakan sebagai pilihan utama dalam terapi pasien infeksi saluran kemih.


Gambar 2 Decision rules of cost-effectiveness analysis

\section{Analisa Sensitivitas}

Analisis sensitivitas digunakan untuk mengatasi ketidakpastian dalam analisis. Analisa ini merupakan interpretasi terhadap nilai rasio efektivitas biaya dari hasil studi farmakoekonomi yang membutuhkan ambang batas (threshold)yang digunakan sebagai pembanding dan untuk menentukan suatu teknologi kesehatan bersifat cost-effective atau tidak (Eichler et al., 2004).

Pada analisis ini, dilakukan pengulangan data analisis setelah mengubah nilai beberapa variabel untuk melihat dampak jika variabel tersebut diubah terhadap hasil secara keseluruhan.

Hasil analisa sensitivitas dapat dilihat pada tabel 8. Analisis sensitivitas memberikan hasil bahwa pada nilai terendah dan tertinggi biaya terapi seftriakson dan siprofloksasin menunjukkan bahwa variasi dari variabel tidak secara esensial mengubah hasil secara keseluruhan. Oleh karena itu, seftriakson merupakan kelompok terapi yang lebih cost-effective. 
JURNAL INOVASI

FARMASI INDONESIA

(JAFI)

Tabel III Total biaya penyakit pasien infeksi saluran kemih sembuh kelompok terapi seftriakson

\begin{tabular}{ccccc}
\hline Komponen biaya & $\begin{array}{c}\text { Jumlah } \\
(\mathbf{R p})\end{array}$ & $\begin{array}{c}\text { Rata-rata } \\
(\mathbf{R p})\end{array}$ & \multicolumn{1}{c}{$\begin{array}{c}\mathbf{\pm S D} \\
(\mathbf{R p})\end{array}$} & $\begin{array}{c}\text { Persentase } \\
(\mathbf{\%})\end{array}$ \\
\hline $\begin{array}{c}\text { Biaya terapi ISK } \\
\text { Biaya Antibiotik } \\
\text { seftriakson }\end{array}$ & $27.247 .470,84$ & $1.009 .165,59$ & $203.265,00$ & 92 \\
\hline Total biaya & $2.452 .651,12$ & $90.838,93$ & $25.614,08$ & 8 \\
\hline & $\mathbf{2 9 . 7 0 0 . 1 2 1 , 9 6}$ & $\mathbf{1 . 1 0 0 . 0 0 4 , 5 2}$ & $\mathbf{2 2 8 . 8 7 9 , 0 8}$ & $\mathbf{1 0 0}$ \\
\hline
\end{tabular}

Sumber : data mentah yang diolah

Tabel IV Total biaya penyakit pasien infeksi saluran kemih sembuh kelompok terapi siprofloksasin

\begin{tabular}{|c|c|c|c|c|}
\hline Komponen biaya & $\begin{array}{c}\text { Jumlah } \\
\text { (Rp) }\end{array}$ & $\begin{array}{l}\text { Rata-rata } \\
\text { (Rp) }\end{array}$ & $\begin{array}{l} \pm \text { SD } \\
\text { (Rp) }\end{array}$ & $\begin{array}{c}\text { Persentase } \\
(\%)\end{array}$ \\
\hline Biaya terapi ISK & $30.982 .423,12$ & $968.200,72$ & $229.247,85$ & 92 \\
\hline $\begin{array}{l}\text { Biaya Antibiotik } \\
\text { siprofloksasin }\end{array}$ & $2.690 .241,84$ & $84.070,06$ & $31.101,97$ & 8 \\
\hline Total biaya & $33.672 .664,96$ & $1.052 .270,78$ & $260.349,82$ & 100 \\
\hline
\end{tabular}

Sumber : data mentah yang diolah

Tabel V Total biaya terapi infeksi saluran kemih gagal terapi

\begin{tabular}{lcl}
\hline Jenis Biaya & $\begin{array}{c}\text { Seftriakson } \\
(\mathbf{R p})\end{array}$ & \multicolumn{1}{c}{$\begin{array}{c}\text { Siprofloksasin } \\
(\mathbf{R p})\end{array}$} \\
\hline Biaya terapi ISK : & & \\
$-\quad$ Biaya kelas perawatan & $87.114,88 \pm 40.277,72$ & $128.915,04 \pm 94.120,88$ \\
$-\quad$ Biaya penunjang terapi & $85.318,40 \pm 66.082,86$ & $81.475,68 \pm 57.625,15$ \\
Biaya Antibiotik & $28.710,00 \pm 11.484,00$ & $50.585,74 \pm 10.283,01$ \\
\hline Subtotal & $201.143,27 \pm 123.469,60$ & $328.033,12 \pm 246.324,59$ \\
\hline
\end{tabular}

Sumber : data mentah yang diolah

Tabel VI Biaya efek samping terapi infeksi saluran kemih sembuh

\begin{tabular}{ccc}
\hline Jenis Biaya & $\begin{array}{c}\text { Seftriakson } \\
(\mathrm{Rp})\end{array}$ & $\begin{array}{c}\text { Siprofloksasin } \\
(\mathrm{Rp})\end{array}$ \\
\hline Biaya Efek Samping & $11.490,38 \pm 9,02$ & $71.470,38 \pm 27.856,81$
\end{tabular}

Sumber : data mentah yang diolah 
JURNAL INOVASI

FARMASI INDONESIA

(JAFI)

Tabel VII Nilai ACER dan Efektivitas masing-masing kelompok terapi

\begin{tabular}{ccccc}
\hline Kelompok terapi & $\begin{array}{c}\text { Biaya } \\
(\mathrm{Rp})\end{array}$ & Efektivitas & $\begin{array}{c}\text { ACER } \\
(\mathrm{Rp})\end{array}$ & $\begin{array}{c}\text { ICER } \\
\text { (Rp) }\end{array}$ \\
\hline Seftriakson & $1.153 .359,17$ & 0,84 & $1.366 .938,13$ & $-835.288,32$ \\
Siprofloksasin & $1.281 .265,83$ & 0,69 & $1.855 .226,54$ & \\
\hline
\end{tabular}

Tabel VIII Analisa sensitivitas tiap kelompok terapi seftriakson dan siprofloksasin

Variabel

Rentang: tertinggi-

Seftriakson :

Siprofloksasin :

$\triangle$ Overall cost :

Overall cost

Overall cost

Seftriakson -

Siprofloksasin

\begin{tabular}{|c|c|c|c|c|c|}
\hline Base case & & Rp 1.153.359,17 & Rp 1.281.265,83 & $\mathrm{Rp}$ & $(127.906,66)$ \\
\hline \multirow{2}{*}{$\begin{array}{l}\text { Biaya terapi } \\
\text { Efek Samping }\end{array}$} & $L=\operatorname{Rp} \quad 8.345,04$ & Rp $1.153 .162,60$ & Rp 1.377.440,16 & $\mathrm{Rp}$ & $(224.277,56)$ \\
\hline & $\mathrm{H}=\mathrm{Rp} 191.942,00$ & Rp 1.164.636,76 & Rp $1.188 .477,00$ & $\mathrm{Rp}$ & $(23.840,24)$ \\
\hline \multirow{2}{*}{$\begin{array}{l}\text { Biaya terapi } \\
\text { Seftriakson }\end{array}$} & $L=R p \quad 640.335,94$ & Rp $\quad 680.856,15$ & Rp $\quad 856.340,26$ & $\mathrm{Rp}$ & $(175.484,11)$ \\
\hline & $\mathrm{H}=\mathrm{Rp} 1.779 .709,60$ & Rp 1.749.023,23 & Rp 1.821.247,26 & $\mathrm{Rp}$ & $(72.224,03)$ \\
\hline \multirow{2}{*}{$\begin{array}{l}\text { Biaya Terapi } \\
\text { Siprofloksasin }\end{array}$} & $\mathrm{L}=\mathrm{Rp} \quad 701.834,96$ & $\mathrm{Rp} \quad 738.511,71$ & $\mathrm{Rp} \quad 908.422,24$ & $\mathrm{Rp}$ & $(169.910,53)$ \\
\hline & $H=\operatorname{Rp} 1.857 .536,96$ & Rp 1.821.986,67 & $\operatorname{Rp} 1.887 .157,30$ & $\mathrm{Rp}$ & $(65.170,63)$ \\
\hline $\begin{array}{c}\text { Probabilitas } \\
\text { ES } \\
\text { Seftriakson } \\
\text { Probabilitas }\end{array}$ & $1 \%$ & Rp 1.159.988,86 & Rp 1.152.515,26 & $\mathrm{Rp}$ & $3.473,61$ \\
\hline $\begin{array}{c}\text { ES } \\
\text { Siprofloksasin }\end{array}$ & $1,8 \%$ & Rp 1.156.443,53 & Rp 1.159.685,26 & $\mathrm{Rp}$ & $(3.241,73)$ \\
\hline
\end{tabular}

Keterangan : probabilitas ES seftriakson dan siprofloksasin (www.accessdata.fda.gov/label), tanda kurung menunjukkan nilai negative 
JURNAL INOVASI

FARMASI INDONESIA

(JAFI)

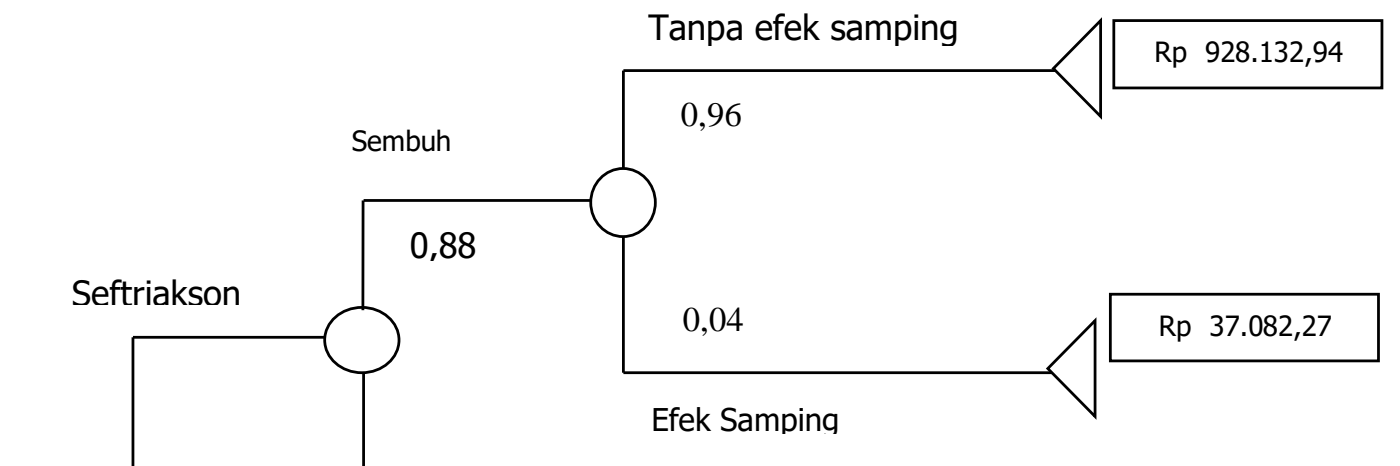

Rp 1.153.359,17
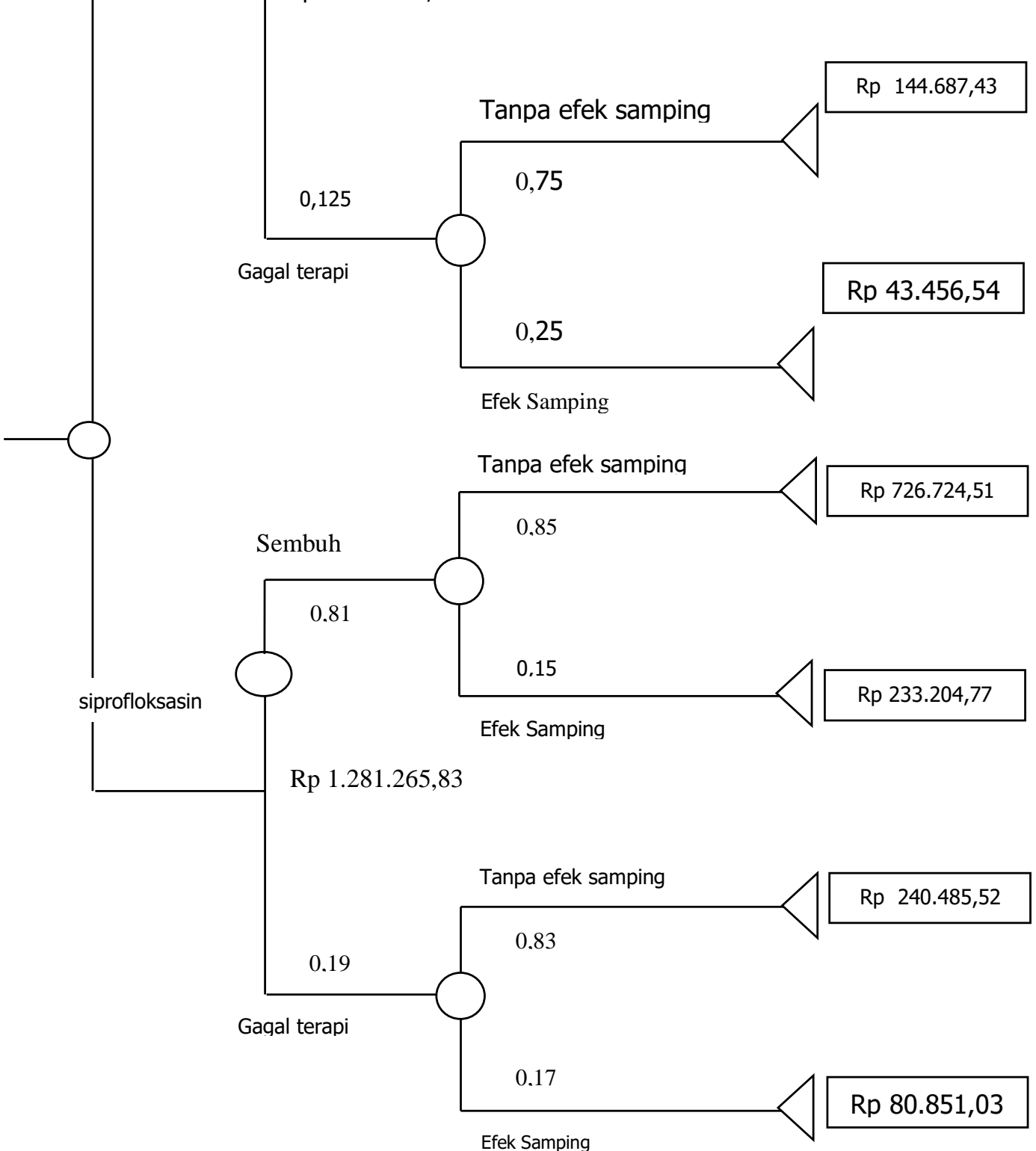

Gambar 3 Decision tree Analysis 


\section{KESIMPULAN}

Berdasarkan penelitian yang telah dilakukan, dapat disimpulkan bahwa pada pasien ISK, kelompok terapi seftriakson lebih cost-effective daripada kelompok terapi siprofloksasin di RSUD Jombang Tahun 2017. Hal ini disebabkan karena dilihat dari perbandingan nilai ACER Seftriakson (Rp 1.366.938,13) lebih kecil daripada nilai ACER Siprofloksasin (Rp 1.855.226,54). Nilai ICER sebesar Rp - 835.288,32. Nilai ICER menunjukkan bahwa seftriakson lebih cost-effective daripada siprofloksasin.

\section{UCAPAN TERIMA KASIH}

Ucapan terima kasih kami sampaikan kepada seluruh pihak RSUD Jombang yang telah sangat mendukung dalam penelitian ini. Kami berharap akan selalu bisa bekerjasama demi mendukung selalu kemajuan dan kualitas RSUD Jombang.

\section{DAFTAR PUSTAKA}

Andayani Sp. FRS., P. A. (2013). Farmakoekonomi Prinsip dan Metodologi. Yogyakarta: Bursa Ilmu.

Bidel et al, M. R. (2016). Fluoroquinolone and Third-Generation-Cephalosporin Resistance among Hospitalized Patients with Urinary Tract Infections Due to Escherichia coli: Do Rates Vary by Hospital Characteristics and Geographic Region? American Society For Microbiology .

Crotty et al. 2017. Allergic Reactions in Hospitalized Patients With a Self-Reported Penicillin Allergy Who Receive a Cephalosporin or Meropenem. Journal of Pharmacy Practice 2017, Vol. 30(1) 42-48. Department of Pharmacy, NSLIJ Huntington Hospital, 270 Park Avenue, Huntington, NY 11743, USA.

Dipiro et al, J. T. (2012). Pharmacotherapy Handbook 9th edition.

Kasmed. 2007. Hubungan Antara Kualitas Perawatan Kateter dengan Kejadian Infeksi Nosokomial Saluran Kemih. Universitas Diponegoro, Semarang.

Lin, Hsin-An et al. 2016. Comparison of the effectiveness and antibiotic cost among seftriakson, ertapenem, and levofloksasin treatment of community-acquired complicated urinary tract infections. Journal of Microbiology, Immunology, and Infection (2016) 49, 237-242. ScienceDirect. Taiwan

A. Oreagba et al. (2017). Adverse reactions to fluoroquinolones in the Nigerian population: an audit of reports submitted to the National Pharmacovigilance Centre from 2004 to 2016. British Pharmacological Society and American Society for Pharmacology and Experimental Therapeutics. Pharmacology Research \& Perspectives. Lagos State University College of Medicine, Ikeja, Lagos, Nigeria 
Lane, David R et al. 2011. Diagnosis and Management of Urinary Tract Infection and Pyelonephritis. Emerg Med Clin N Am 29 (2011) 539-552. Elsevier Inc. All rights reserved

Pranoto et al. (2012). Infeksi Saluran Kemih di Instalasi Rawat Inap RSUD Banyumas Periode Agustus 2009 - Juli 2010. Pharmacy, Vol 09.

Ruru, Rany Inggrid, Citraningtyas Gayatri et al. 2018. Analisis Efektivitas Biaya Pengobatan Infeksi Saluran Kemih Menggunakan Antibiotik Seftriakson dan Siproflokasin di RSUP Prof. DR. R. D. Kandou. Jurnal Ilmiah Farmasi UNSRAT Vol. 7 No. 3 Agustus 2018 ISSN 2302-2493 